\title{
The caridean shrimps of the genus Lysmata Risso, 1816 (Decapoda: Lysmatidae) from Madagascar collected during the Atimo-Vatae expedition: a new species and two new records
}

\author{
Hossein ASHRAFI (1, 1, , J. Antonio BAEZA $0^{2} \&$ Zdeněk ĎURIŠ $\oplus^{3}$ \\ ${ }^{1,3}$ Department of Biology and Ecology, Faculty of Science, University of Ostrava, \\ Ostrava, Czech Republic. \\ ${ }^{2}$ Department of Biological Sciences, 132 Long Hall, Clemson University, Clemson, SC 29634, USA \\ and Smithsonian Marine Station at Fort Pierce, 701 Seaway Drive, Fort Pierce, FL 34949, USA \\ and Departamento de Biología Marina, Facultad de Ciencias del Mar, Universidad Católica del Norte, \\ Larrondo 1281, Coquimbo, Chile. \\ *Corresponding author: ashrafi.hossein.s@gmail.com \\ 2Email: jbaezam@clemson.edu \\ ${ }^{3}$ Email: zdenek.duris@osu.cz \\ ${ }^{1}$ urn:1sid:zoobank.org:author:9434EF55-A729-481B-A0BB-B2F82EC2BFC3 \\ ${ }^{2}$ urn:1sid:zoobank.org:author:4A72F2F5-6C56-4800-91BE-E9E671AACDFE \\ ${ }^{3}$ urn:lsid:zoobank.org:author:0CF5D3F9-9663-4B76-BF91-713D9BE50BC3
}

\begin{abstract}
The present study focuses on shrimps belonging to the genus Lysmata Risso, 1816, collected from Madagascar during the Atimo Vatae expedition carried out in 2010. Lysmata malagasy sp. nov. is a new species belonging to the clade named "long accessory ramous" or "cosmopolitan" in previous phylogenetic studies. The new species can be distinguished from the only two other representatives of this group in the Indo-west Pacific, L. ternatensis De Man, 1902, and L. trisetacea (Heller, 1861), by the accessory ramus of the lateral antennular flagellum consisting of four elongated articles. Lysmata lipkei Okuno \& Fiedler, 2010 is reported here from Madagascar with a remarkable extension of its known range after its original description from Japan. This species has also been reported from Singapore and, as alien species, from Brazil. Lastly, L. kuekenthali De Man, 1902 known from numerous localities in the Indo-West Pacific biogeographic area, is reported for the first time from Madagascar. Results of the present morphological and molecular analyses suggest that $L$. hochi Baeza \& Anker, 2008 from the Caribbean Sea is a synonym of the Indo-West Pacific L. kuekenthali, and thus the latter species is alien in the western Atlantic.
\end{abstract}

Key words. Lysmata malagasy sp. nov., L. lipkei, L. kuekenthali, alien species, L. hochi.

Ashrafi H., Baeza J.A. \& Ďuriš Z. 2021. The caridean shrimps of the genus Lysmata Risso, 1816 (Decapoda: Lysmatidae) from Madagascar collected during the Atimo-Vatae expedition: a new species and two new records. European Journal of Taxonomy 774: 155-177. https://doi.org/10.5852/ejt.2021.774.1535 


\section{Introduction}

The caridean shrimp genus Lysmata Risso, 1816 is the largest genus with 47 species in the relatively small family Lysmatidae Dana, 1852 (Chace 1997; Wicksten 2000; De Grave \& Fransen 2011; De Grave et al. 2014). The species belonging to this genus live in the intertidal zone and down to $360 \mathrm{~m}$ depth in tropical, subtropical, and temperate regions worldwide (Crosnier \& Forest 1973; Fransen 1991; Chace 1997; Anker \& Cox 2011; Rhyne et al. 2012; Wang \& Sha 2018). The genus was subdivided into several groups based on morphological features, ecological, and molecular data (Bauer 2000; Rhyne \& Lin 2006; Baeza et al. 2009; Fiedler et al. 2010). The first division of the genus was conducted by Bauer (2000), suggesting the presence of two groups, the "cleaner" group mostly comprised of pair-living species that are active fish cleaners and feature conspicuous yellow and red colorations, and the "peppermint" group mostly comprised of species living in large aggregations that are not active fish cleaners, and with transverse or longitudinal red bands in the body. Rhyne \& Lin (2006) added another group to Bauer's division, characterized by having a long free (accessory) ramus of the lateral antennular flagellum.

In the first published comprehensive molecular phylogeny of the genus Lysmata, Baeza et al. (2009) named three different clades: 1) the 'Tropical-American clade' (occurring in the tropical western Atlantic and eastern Pacific), 2) the cleaner clade, and 3) the cosmopolitan clade, with the latter being the same as "long accessory ramous clade", sensu lato. Lastly, a more comprehensive phylogenetic analysis conducted by Baeza (2010), revealed a fourth clade named the "morpho-variable clade" that includes $L$. hochi and L. vittata, together with two species belonging to genus Exhippolysmata Stebbing, 1915, i.e., E. ensirostris (Kemp, 1914), and E. oplophoroides (Holthuis, 1948). In the same year, Fiedler et al. (2010) discriminated three groups based on the accessory ramus of the lateral antennular flagellum, establishing: 1) the "short accessory ramous" group (with the cleaner clade belonging to this group); 2) the "long accessory ramous" group, and 3) the "unguiform ramous" group. The latter group is similar to the "morpho-variable" clade defined by Baeza (2010) but excluding the genus Exhippolysmata.

Importantly, free-living species in the genus appear to show a high potential for invading other regions, considering that four species so far have been recorded as alien: $L$. hochi Baeza \& Anker, 2008 in India (Jose et al. 2020), L. kempi Chace, 1997 in Turkey (Froglia \& Deval 2014), L. lipkei Okuno \& Fiedler 2010 in Brazil (Alves et al. 2018), and L. vittata (Stimpson, 1860) in Brazil too (Soledade et al. 2013; Alves et al. 2018).

During the recent Atimo Vatae expedition to south Madagascar, conducted by the Museum national d'histoire naturelle (MNHN) under the "Our Planet Reviewed" program in 2010, three different species of the genus Lysmata were collected. After a detailed comparison of the captured specimens, one of them was identified as new to science. The remaining two species belong to currently known Indo-West Pacific representatives of the genus, L. kuekenthali (De Man, 1902), and L. lipkei Okuno \& Fiedler, 2010. The new species is described, and the new records of the two other species are reported here.

Based on phylogenetic trees (Maximum Likelihood and Bayesian Inference) constructed using the 16S mitochondrial gene marker, the relationship of the new species with the other species of the "long accessory ramous" clade was examined. Also, new sequences belonging to L. kuekenthali and L. lipkei were compared with previously reported sequences retrieved from congeneric specimens to confirm their species affiliations, and to highlight their relationship to other currently recognized taxa.

\section{Material and methods}

\section{Taxon sampling}

The material from Madagascar was collected during the Atimo Vatae expedition in 2010 from intertidal and shallow subtidal zones in Fort-Dauphin (Tolagnaro), between April $27^{\text {th }}$ and May $17^{\text {th }}$, and from 
Lavanono, between May $23^{\text {rd }}$ and June $13^{\text {th }}$, by means of SCUBA diving and light dredging. Moreover, a shrimp trawler was used to sample by dredging and trawling, conducting 119 hauls at depths between 50 and $700 \mathrm{~m}$. The material of this expedition was deposited in MNHN, and during the visit of the collection by HA and ZD early in 2020, the examined specimens were loaned from the museum for this study.

In addition to material from Madagascar, two other specimens belonging to L. kuekenthali from the Gulf of Oman (Ashrafi et al. 2020) were included in this study. Moreover, sequence data from prior studies were used to construct phylogenetic trees (Table 1). The material from the Iranian coast in the Gulf of Oman was collected during a spring tide at night from the low intertidal zone. Shrimps belonging to the genus Lysmata are active at night, and thus, they can be captured during dark hours using a flashlight.

\section{DNA extraction, amplification, and sequencing}

Total genomic DNA was extracted from the tissues of one of the fifth pereiopods or fourth or fifth pleopods using the DNeasy Blood \& Tissue Isolation Kit (QIAGEN) according to the manufacturer's protocol. The polymerase chain reaction was used to amplify a partial segment of the 16S rRNA gene (aproximately $550 \mathrm{bp}$ ), using the primers AR pal (Palumbi \& Benzie 1991) for forward and 1472 (Crandall \& Fitzpatrick 1996) for reverse. A total volume of $20 \mu$ including $4 \mu \mathrm{l} 5 \mathrm{x}^{\text {MyTaq }}{ }^{\mathrm{TM}}$ Red Reaction buffer (comprising $15 \mathrm{mM} \mathrm{MgCl} 2$ and $5 \mathrm{mM}$ dNTPs), $1 \mu \mathrm{l}$ DNA template, $13.2 \mu \mathrm{dH} 2 \mathrm{O}$, $0.8 \mu \mathrm{l}$ of each primer, and $0.2 \mu \mathrm{l} \mathrm{MyTaq}{ }^{\mathrm{TM}}$ Red DNA polymerase were used for PCR. The thermocycler sequencing conditions were set according to Horká et al. (2016): $2.5 \mathrm{~min}$ at $90{ }^{\circ} \mathrm{C}$, followed by 10 cycles of $50 \mathrm{~s}$ at $92{ }^{\circ} \mathrm{C}, 30 \mathrm{~s}$ at $42-48^{\circ} \mathrm{C}$, and $1 \mathrm{~min}$ at $72{ }^{\circ} \mathrm{C}, 36$ cycles of $30 \mathrm{~s}$ at $92{ }^{\circ} \mathrm{C}, 40 \mathrm{~s}$ at $42-$ $48{ }^{\circ} \mathrm{C}$, and $1 \mathrm{~min}$ at $72{ }^{\circ} \mathrm{C}$ and a final extension step at $72{ }^{\circ} \mathrm{C}$ for $3 \mathrm{~min}$. The final products were purified by the GenElute PCR Clean-up kit (Sigma-Aldrich), and sent to Macrogen, Amsterdam for forward and reverse sequencing (performed by an ABI3730XL DNA Sequencer), and therefore, complement sequences were used for the following steps.

\section{Sequence alignment and tree construction}

Obtained forward and reverse sequences were checked by eye and corrected if necessary in the case forward and reverse sequences were not a complete match, using Chromas ver. 2.4.1. Aligning was carried out using the software MUSCLE (Edgar 2004), with default setting, as implemented in MEGA-X (Kumar et al. 2018). Highly variable and divergent positions as well as poorly aligned ones were detected and eliminated from the alignment using Gblocks v0.91b (Castresana 2000) with default parameters except for allowing gap positions. As a result, 358 out of 513 nucleotides were determined to be suitable for phylogenetic analysis.

The best-fit model for the nucleotide substitution (i.e., TIM3 $+\mathrm{F}+\mathrm{I}+\mathrm{G} 4$ ) was selected based on AIC (Akaike Information Criterion) using the software IQ-TREE ver. 2.0.5 (Kalyaanamoorthy et al. 2017). The Maximum Likelihood analysis was conducted with the web server IQ-TREE with default options except for the number of bootstrap alignments set to 10000 with the 'ultrafast' option selected for 'bootstrap analysis'.

A Bayesian tree was constructed using MrBayes ver. 3.2.7 (Ronquist \& Huelsenbeck 2003). The MCMC analysis was set for $8 \times 10^{6}$ generations with four chains and two independent runs. Each run was sampled every 500 generations, and the first $25 \%$ of trees in each run were discarded as "burnin". The remaining trees were used for constructing the 50\% majority role consensus tree and also for calculating Bayesian posterior probabilities (bpp). The final tree was displayed using the online application ITOL (Letunic \& Bork 2011). 


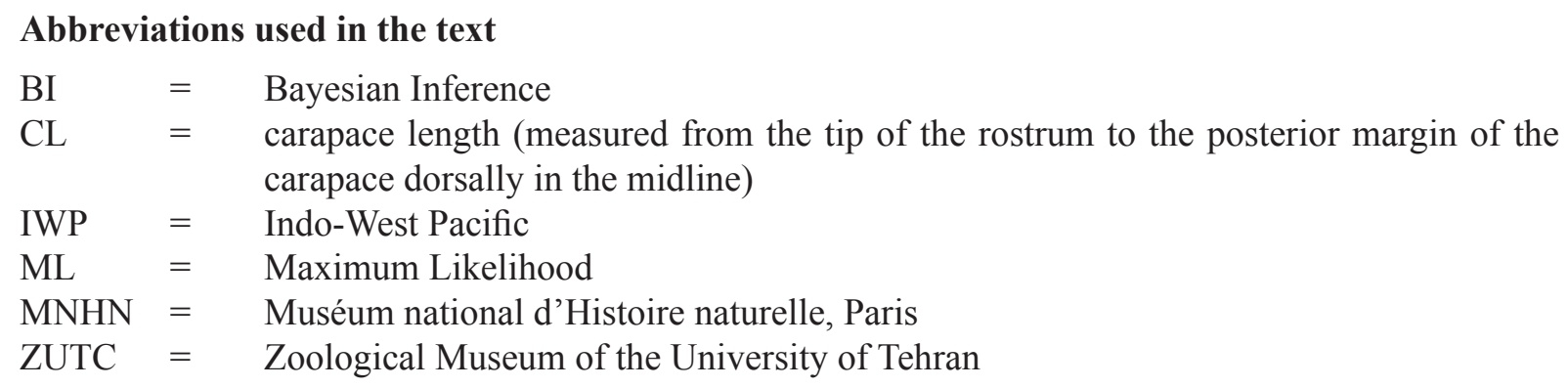

\section{Results}

\section{Molecular analysis}

In the present study, the two constructed phylogenetic trees (ML and BI; Figs. 1-2, respectively) somewhat differ from each other. The previously recognized "long accessory ramous" and "unguiform accessory ramous" clades are well (BI) or strongly (ML) supported by our analyses. The former clade forms a subclade consisting of $L$. cf. trisetacea (Heller, 1861), L. intermedia (Kingsley, 1878), L. nilita Dohrn \& Holthuis, 1950, L. moorei (Rathbun, 1901), and L. galapagensis Schmitt, 1924 in both trees, with high support in the BI analysis. The other species that belong to this clade form a polytomy in the BI analysis, but they form a clade in the ML analysis that was not well-supported by bootstrap values.

The 'Tropical American clade' is sister to all other clades and species of Lysmata in the two (ML and BI) phylogenetic trees. Importantly, this 'Tropical American clade' does not cluster and forms a monophyletic clade with representatives from the "short accessory ramous" group. Thus, the "short accessory ramous" group does not appear to be monophyletic in the present analyses. Furthermore, L. olavoi Fransen, 1991, is the single species that does not cluster together with any of the previously defined clades in the genus Lysmata (see Baeza et al. 2009 and Baeza 2010). In our analysis, the "unguiform ramous" group defined by Fiedler et al. (2010) is retrieved as a well-supported monophyletic clade.

The position of three problematic species mentioned by Fiedler et al. (2010) remains unresolved also in the present analyses. In addition to Lysmata olavoi that does not cluster with any other groups (see above), two "peppermint shrimps", L. nayaritensis Wicksten, 2000 and L. californica (Stimpson, 1866), form a monophyletic clade and cluster with members of the "cleaner clade". The latter group is still monophyletic, although with relatively low support in the BI tree. However, the "cleaner clade" is paraphyletic in the ML tree as L. nayaritensis is nested inside.

Lysmata malagasy sp. nov. belongs to the "long accessory ramous" clade. However, the position of this species within the clade in the ML and BI phylogenetic trees is different. In the ML analysis, the new species is closest to L. ternatensis, and both form a poorly-supported subclade with L. argentopunctata Wicksten, 2000 and L. seticaudata (Risso, 1816). In the BI analysis, the new species does not cluster together with any other representative of the "long accessory ramous" clade.

The analysed specimens of Lysmata kuekenthali (De Man, 1902), L. hochi Baeza \& Anker, 2008, L. lipkei Okuno \& Fiedler, 2010, and L. cf. anchisteus Chace, 1972 form a well-supported clade that represents the "unguiform ramous" clade previously defined by Fielder et al. (2010). The specimen of $L$. hochi is nested inside the group of $L$. kuekenthali specimens pointing to the possibility that $L$. hoch $i$ and L. kuekenthali might be the same species (see below). 
Table 1. Specimen information about the material used to construct the phylogenetic tree.

\begin{tabular}{|c|c|c|c|}
\hline Taxon & Source & Voucher number & $\begin{array}{l}\text { GenBank accession } \\
\text { number }\end{array}$ \\
\hline L. amboinensis & $\begin{array}{l}\text { Fiedler et al. } 2010 \\
\text { Baeza et al. } 2009\end{array}$ & & $\begin{array}{l}\text { HQ315589 } \\
\text { EU861488 }\end{array}$ \\
\hline L. cf. anchisteus & Fiedler et al. 2010 & & HQ315606 \\
\hline L. ankeri & $\begin{array}{l}\text { Fiedler et al. } 2010 \\
\text { Baeza et al. } 2009\end{array}$ & & $\begin{array}{l}\text { HQ315599 } \\
\text { EU861501 }\end{array}$ \\
\hline L. argentopunctata & Baeza 2010 & & GQ227814 \\
\hline L. boggessi & $\begin{array}{l}\text { Baeza \& Behringer } 2017 \\
\text { Fiedler et al. } 2010\end{array}$ & & $\begin{array}{l}\text { MF632247 } \\
\text { HQ315603 }\end{array}$ \\
\hline L. californica & $\begin{array}{l}\text { Baeza et al. } 2009 \\
\text { Fiedler et al. } 2010\end{array}$ & & $\begin{array}{l}\text { EU861499 } \\
\text { HQ315596 }\end{array}$ \\
\hline L. debelius & $\begin{array}{l}\text { Baeza et al. } 2009 \\
\text { Fiedler et al. } 2010\end{array}$ & & $\begin{array}{l}\text { EU861492 } \\
\text { HQ315595 }\end{array}$ \\
\hline L. galapagensis & $\begin{array}{l}\text { Baeza et al. } 2009 \\
\text { Fiedler et al. } 2010\end{array}$ & & $\begin{array}{l}\text { HQ315577 } \\
\text { EU861480 }\end{array}$ \\
\hline L. grabhami & $\begin{array}{l}\text { Baeza et al. } 2009 \\
\text { Fiedler et al. } 2010\end{array}$ & & $\begin{array}{l}\text { HQ315593 } \\
\text { EU861489 }\end{array}$ \\
\hline $\begin{array}{l}\text { L. gracilirostris } \\
\text { L. hochi }\end{array}$ & $\begin{array}{l}\text { Fiedler et al. } 2010 \\
\text { Fiedler et al. } 2010\end{array}$ & & $\begin{array}{l}\text { EU861502 } \\
\text { EU861507 }\end{array}$ \\
\hline L. intermedia & $\begin{array}{l}\text { Baeza et al. } 2009 \\
\text { De Grave et al. } 2014\end{array}$ & & $\begin{array}{l}\text { HQ315580 } \\
\text { KF023094 }\end{array}$ \\
\hline L. kuekenthali & $\begin{array}{l}\text { Baeza \& Fuentes } 2013 \\
\text { Present study-Madagascar } \\
\text { Present study-Iran_1 } \\
\text { Present study-Iran_2 }\end{array}$ & $\begin{array}{l}\text { MNHN-IU-2010-2377 } \\
\text { MNHN-IU-2014-1246 } \\
\text { MNHN-IU-2014-1247 }\end{array}$ & $\begin{array}{l}\text { KC962216 } \\
\text { MW798242 } \\
\text { MW798240 } \\
\text { MW798241 }\end{array}$ \\
\hline L. lipkei & $\begin{array}{l}\text { Baeza et al. } 2009 \\
\text { Present study }\end{array}$ & MNHN-IU-2010-4898 & $\begin{array}{l}\text { HQ315574 } \\
\text { MW798243 }\end{array}$ \\
\hline L. malagasy & Present study & MNHN-IU-2010-4890 & MW798244 \\
\hline L. moorei & $\begin{array}{l}\text { Baeza et al. } 2009 \\
\text { Fiedler et al. } 2010\end{array}$ & & $\begin{array}{l}\text { HQ315578 } \\
\text { EU861481 }\end{array}$ \\
\hline L. nayaritensis & Fiedler et al. 2010 & & EU861506 \\
\hline $\begin{array}{l}\text { L. nilita } \\
\text { L. olavoi }\end{array}$ & $\begin{array}{l}\text { Fiedler et al. } 2010 \\
\text { Fiedler et al. } 2010\end{array}$ & & $\begin{array}{l}\text { EU861482 } \\
\text { EU861494 }\end{array}$ \\
\hline L. pederseni & $\begin{array}{l}\text { Baeza et al. } 2009 \\
\text { Fiedler et al. } 2010\end{array}$ & & $\begin{array}{l}\text { HQ315601 } \\
\text { EU861504 }\end{array}$ \\
\hline L. rafa & $\begin{array}{l}\text { Baeza et al. } 2009 \\
\text { Fiedler et al. } 2010\end{array}$ & & $\begin{array}{l}\text { HQ315604 } \\
\text { EU861495 }\end{array}$ \\
\hline L. seticaudata & $\begin{array}{l}\text { De Grave et al. } 2014 \\
\text { Baeza } 2010\end{array}$ & & $\begin{array}{l}\text { KF023083 } \\
\text { GQ227827 }\end{array}$ \\
\hline L. ternatensis & $\begin{array}{l}\text { Baeza et al. } 2009 \\
\text { Aznar-Cormano et al. } 2015\end{array}$ & & $\begin{array}{l}\text { HQ315584 } \\
\text { KP725548 }\end{array}$ \\
\hline L. cf. trisetacea & Fiedler et al. 2010 & & EU861483 \\
\hline L. wurdemanni & Baeza \& Prakash 2019 & & MG957483 \\
\hline Gelastocaris paronae & Present study & MNHN-IU-2018-1318 & MW798245 \\
\hline
\end{tabular}


Gelastocaris paronae

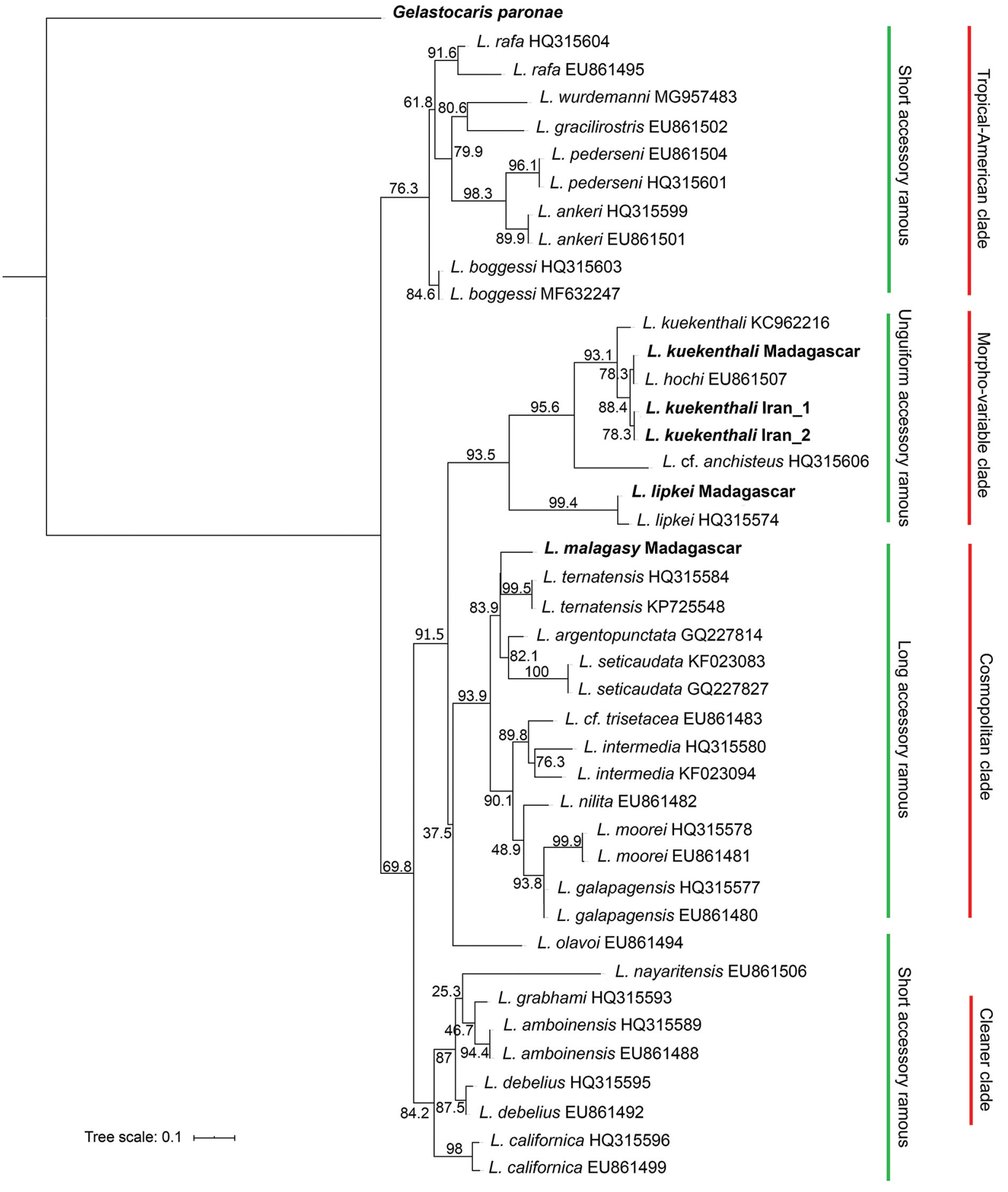

Fig. 1. Phylogenetic tree obtained by Maximum Likelihood analysis based on partial sequences of 16S. Bootstrap support is indicated above or below the branches before the nodes. The material of the present study is shown in bold format. The green vertical lines show the clades defined by Fiedler et al. (2010), and the red ones by Baeza et al. (2009) and Baeza (2010). 


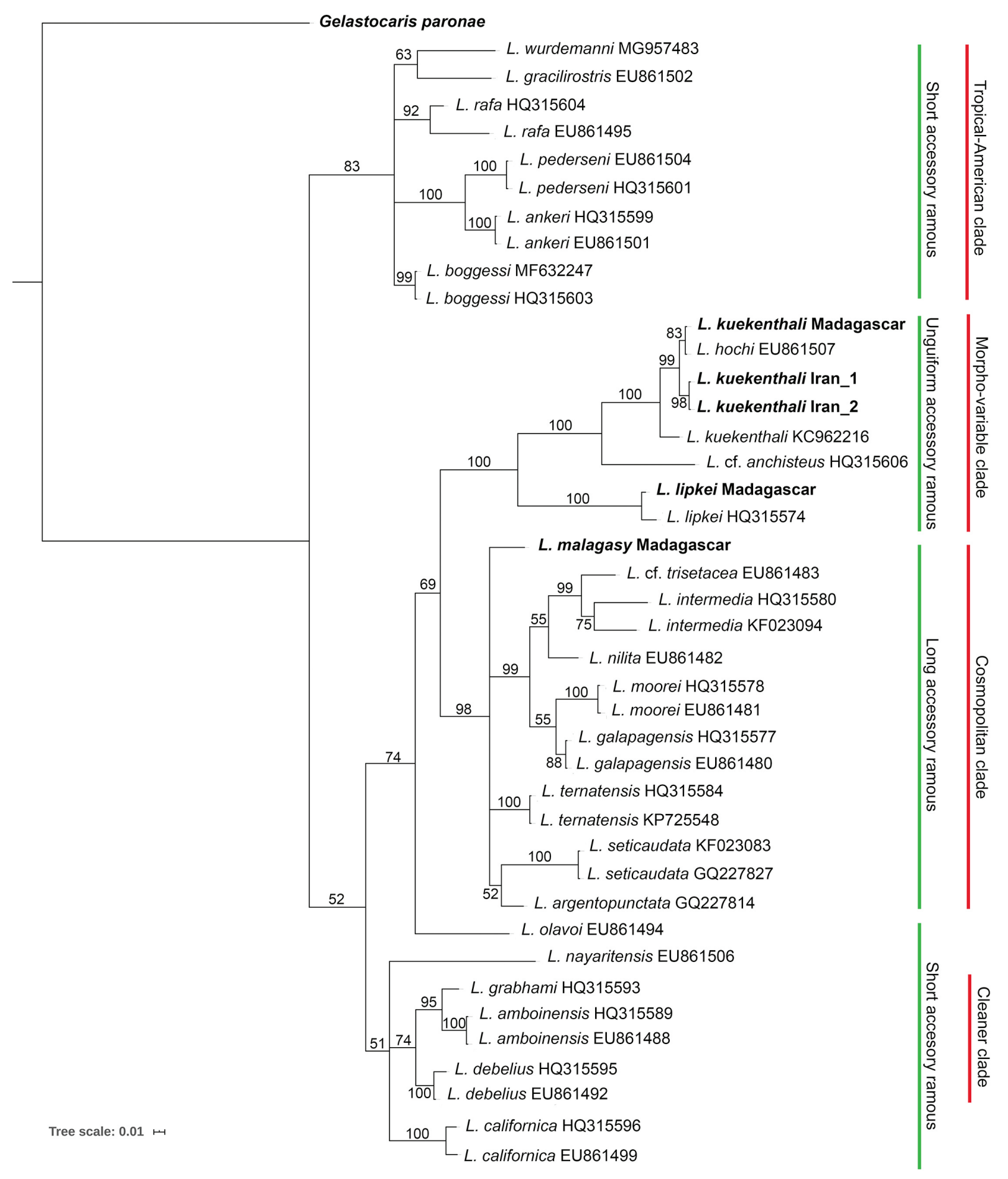

Fig. 2. Phylogenetic tree obtained by Bayesian inference analysis based on partial sequences of 16S. Support for each node is indicated as posterior probabilities above or below the branches before the nodes. The material of the present study is shown in bold format. The green vertical lines show the clades defined by Fiedler et al. (2010), and the red ones by Baeza et al. (2009) and Baeza (2010). 


\section{Systematics}

Subphylum Crustacea Brünnich, 1772

Class Malacostraca Latreille, 1802

Order Decapoda Latreille, 1802

Infraorder Caridea Dana, 1852

Family Lysmatidae Dana, 1852

Genus Lysmata Risso, 1816

Lysmata malagasy sp. nov.

urn:Isid:zoobank.org:act:62A66440-6F8E-4BD3-94E3-5CAD9D2D336E

Figs 3-7

\section{Etymology}

The new species is named after 'Malagasy', the native inhabitants of Madagascar where the specimen was collected; the term 'Malagasy' is English version of the word 'Malgache' in French used for both people and their language in Madagascar; used as a noun in apposition.

\section{Type material}

\section{Holotype}

MADAGASCAR - 1 ovigerous hermaphrodite (CL $8.8 \mathrm{~mm}$ ); southern Madagascar; $24^{\circ} 58^{\prime} 4.8^{\prime \prime} \mathrm{S}$, 4706'8.4" E; depth 3-8 m; 6 May 2010; MNHN exped.; Atimo-Vatae; Stn TR05 1; GenBank MW798244; MNHN-IU-2010-4890.

\section{Description}

\section{Medium-sized lysmatid shrimp}

CARAPACE (Figs 3, 4A-C). Smooth with scattered setae on dorsal margin, antennal tooth strong, pterygostomial margin slightly produced, pointed; with two postrostral dorsal teeth located anteriorly at about 0.2 and 0.4 of carapace length. Rostrum elongated, approximately half of CL, reaching to about

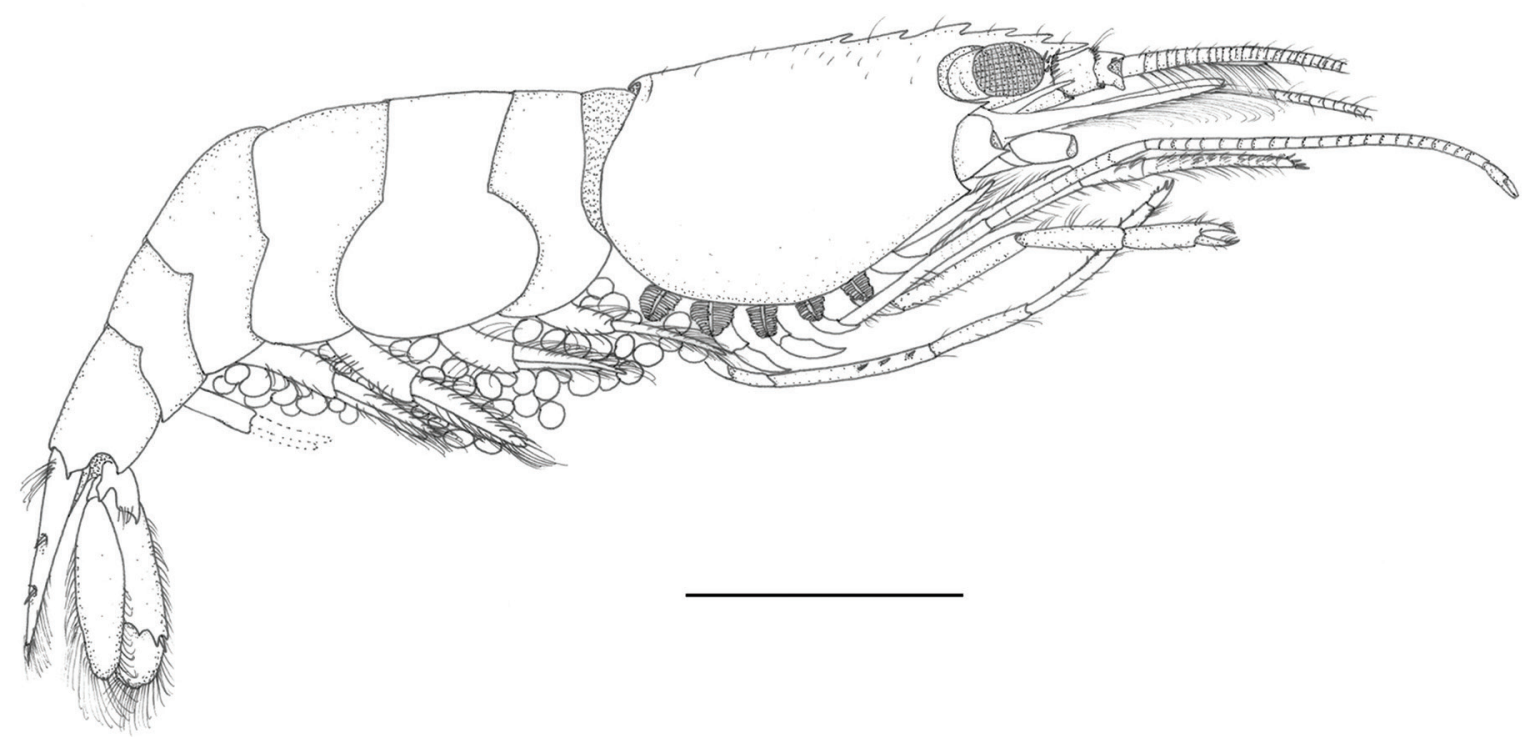

Fig. 3. Lysmata malagasy sp. nov., holotype (MNHN-IU-2010-4890), habitus, lateral view. Scale bar: $5 \mathrm{~mm}$. 




Fig. 4. Lysmata malagasy sp. nov., holotype (MNHN-IU-2010-4890). A. Anterior region, lateral view. B. Same, dorsal view. C. Rostrum, lateral view. D. Uropods, dorsal view. E Telson, dorsal view. 
end of second antennular article, straight in lateral view, bearing evenly distributed three teeth dorsally; ventral margin with two teeth at distal-third.

Pleon (Fig. 3). Smooth; first pleuron obtusely angulate anteriorly, rounded postero-ventrally; second and third pleura rounded antero- and postero-ventrally; fourth pleuron angulated postero-ventrally, not pointed; fifth pleuron produced postero-ventrally, subacute; sixth pleuron with triangular projections postero-laterally.

TeLson (Fig. 4E). Elongated, slightly more than twice as long as broadest part, tapering posteriorly; dorsal surface with antero-median tuft of long setae and two pairs of spines about 0.1 of telson length and situated at 0.5 and 0.75 of telson length; distal half of lateral margins furnished with setae; posterior margin broadly triangular, projecting medially into acute apex, with two pairs of slender submedian setae and two pairs of laterally placed spines, mesial spines long, about 1.2 times as long as dorsal spines and more than three times as long as lateral ones, latter small, about 2.5 times as short as dorsal spines.

Antennule (Fig. 4A-B). With peduncle stout; basal peduncular segment longer and stouter than others, reaching about to base of most anterior dorsal rostral tooth, with group of spinules antero-dorsally; stylocerite slender, acute, falling short of reaching to middle of second antennular segment; second peduncular segment stouter and longer than third one, with few spinules along antero-dorsal margin; third segment about 0.7 as long as second one, with row of spinules furnishing distal margin. Lateral (= upper) flagellum biramous, fused part consisting of eight or nine articles (right and left antennule in holotype, respectively), each article of fused part with row of small spinules situated on anterior margin, short free ramus (= accessory ramus) comprising of four elongated articles; aesthetascs present from distal end of first article of fused part to end of short free ramus. Longer free ramus of upper flagellum filiform, each article with one or two small spinules on anterior margin. Lower antennular flagellum filiform, long.

Antenna (Fig. 4A-B). With scaphocerite about 0.8 as long as CL, elongated, five times as long as broad, lateral margin straight, distolateral tooth acute, slightly overreaching blade, slightly overreaching fused part of lateral antennular flagellum, basicerite with acute inferior tooth, falling short of middle of cornea, superior margin rounded; carpocerite small, reaching to about end of first antennular segment.

EYES. With cornea about 0.2 of CL, stalk about a third of cornea.

Mouth PARTs. Not dissected except for third maxilliped. Second maxilliped with podobranch. Third maxilliped (Fig. 5A) pediform, bearing broadly hooked lateral plate, group of short distolateral setae, strap-like epipod, and arthrobranch. Endopodite stout, with numerous slender serrulate setae dorsally as well as ventrally; antepenultimate segment long, slender, more than nine times as long as deep; penultimate segment about 0.4 as long as antepenultimate one, four times as long as deep; ultimate segment long, slender, slightly tapering distally, approximately 0.75 as long as antepenultimate segment, bearing three terminal spinules and single similar subterminal one. Exopodite feebly developed, reaching to distal two thirds of antepenultimate segment, distal half with numerous slender marginal setae.

FIRST PEREIOPOD (Fig. 5B-C). As in other lysmatid shrimps, similar, equal, smaller than other pereiopods, slightly overreaching scaphocerite when extended; coxa with strap-like epipod and tuft of numerous long setobranchs; basis small, with no special structures; ischium about three times as long as basis, with several small spinules and several thick setae on ventral margin; merus nearly twice as long as ischium, about 5.5 times as long as broadest part in midlength, with few thick setae on mid-ventral margin; carpus about 0.8 times as long as merus, more than three times as long as broad, furnishing with setal brush disto-ventro-mesially; chela with palm elongated, more than 1.5 times as long as fingers, lacking thick setae; fingers simple, without gap when closed. 


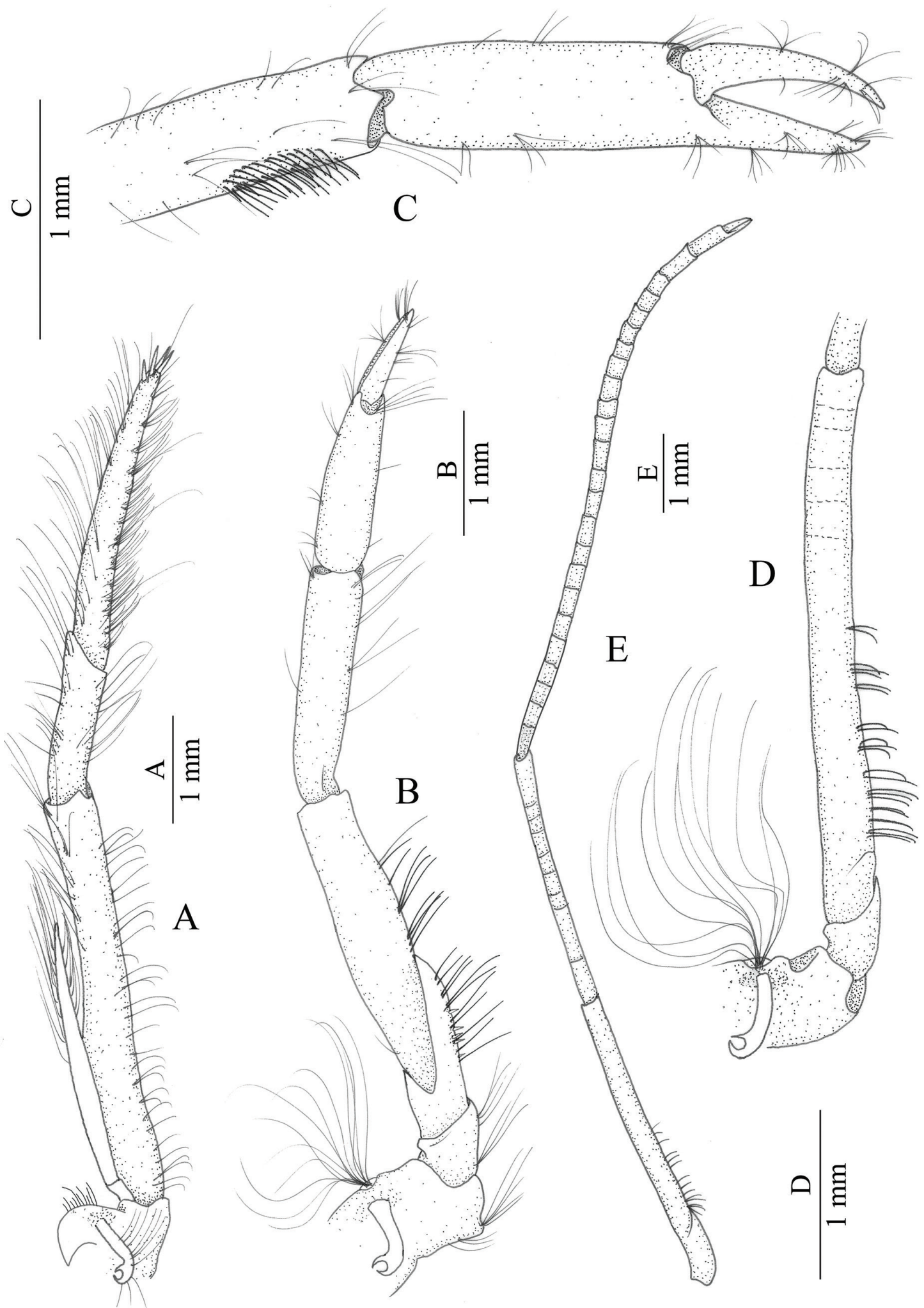

Fig. 5. Lysmata malagasy sp. nov., holotype (MNHN-IU-2010-4890). A. Third maxilliped, lateral view. B. First pereiopod, lateral view. C. Same, mesial view. D. Proximal parts of second pereiopod, lateral view. E. Distal parts of second pereiopod, lateral view. 
SeCond Pereiopods (Fig. 5D-E). Subequal, similar, about 2.5 times as long as CL, more slender than other pereiopods, coxa with strap-like epipod and tuft of numerous setobranchs; basis short; ischium long, about 7 times as long as basis, with relatively thick setae on ventral margin at proximal-half, distal half with several weak subdivisions; merus long, about 0.8 as long as ischium, with eight articles; carpus long, more than twice as long as merus, subdivided into 23 articles; chela small, with palm about 1.5 times as long as fingers, fingers simple.

THIRD PEREIOPOD (Fig. 6A-B). Longer than other walking pereiopods; coxa with strap-like epipod and tuft of numerous setobranchs; merus more than three times as long as ischium, with two rows of spines on latero-ventral margin, one row with five and other row with three spines; carpus about 0.5 times as long as merus, with two rows of spines, each row with three spines; propodus about 1.3 times as long as carpus, bearing two rows of spines on ventral margin and one pair distally, each row with eight spines; dactylus biunguiculate, superior unguis slightly longer than inferior, inferior unguis slightly broader at base than superior, flexor margin with three accessory spines.

FOURTH PEREIOPOD (Fig. 6C-D). Generally similar to third one, carpus with only one spines on ventral margin, propodus with single row of seven spines ventrally and one pair distally.

FIFTH PEREIOPOD (Fig. 6E). Generally similar to fourth pereiopod; with coxa bearing setobranchs, without strap-like epipod; merus with only one row of three spines implemented ventrally; carpus unarmed, propodus with two small transverse row of cleaning setae distally on ventro-mesial margin.

UROPOD (Fig. 4D). With dorso-distal end of protopod acute; rami subequal, broadly subovate; exopod approximately twice as long as broad, with lateral margin straight ending distolaterally into 'trispinose' arrangement of two strong teeth - acute lateral and subacute mesial one, with slender and longer movable spine between teeth; mesial distolateral tooth situated laterally on diaeresis, latter sinuous, with obtuse median projection and subacute projection mesially.

\section{Color pattern}

BoDy (Fig. 7). Transparent to semi-transparent with one broad reddish brown coloured stripe mid-dorsally on carapace and four similar irregular longitudinal stripes on the sides, all continuing posteriorly to end of sixth pleonite; lateral pleonal stripes regular in shape. Reddish-brown broad stripes interspaced with narrow whitish longitudinal paths with series of white dots in midline. Outer antennular flagella bright red, inner flagellum pinkish; third maxillipeds and pereiopods pinkish proximally with gentle gradient toward distal parts, darker in articulations, distal margin of palm and fingers of first pereiopods pinkish red; uropods and telson reddish brown without any stripes; eggs kiwi-fruit-flesh green.

\section{Remarks}

The phylogenetic analysis places the present new species into the "long accessory ramous" clade of the genus Lysmata in both ML (Fig. 1) and BI (Fig. 2) analyses. In the ML analysis, L. malagasy sp. nov. forms a subclade; however, not well-supported, together with $L$. ternatensis, L. argentopunctata and $L$. seticaudata, with $L$. ternatensis being the closest species to the new species. In the BI analysis, the relationships of the new species to other species belonging to the "long accessory ramous" clade is not clear as L. malagasy sp. nov. forms no subclade with any other species of the clade.

Considering the division of the genus into three clades morphologically distinguishable by the state of the shorter free (= accessory) ramus of the lateral antennular flagellum i.e., short with one article, unguiform with one finger-like article, or long with multiple articles (Fiedler et al. 2010), the new species L. malagasy sp. nov. belongs to the third group, i.e., the "long accessory ramous" which represents a well-supported monophyletic clade in previous phylogenetic studies (Baeza et al. 2009; Baeza 2010; 




Fig. 6. Lysmata malagasy sp. nov., holotype (MNHN-IU-2010-4890). A. Third pereiopod, lateral view. B. Same, mesial view. C. Fourth pereiopod, lateral view. D. Dactylus of fourth pereiopod, mesial view. E. Fifth pereiopod, lateral view. 
Fiedler et al. 2010; Baeza \& Fuentes 2013). In the study of Baeza et al. (2009), Baeza (2010), and Baeza \& Fuentes (2013), this clade was named the "cosmopolitan clade". The Atlantic representatives of this clade are Lysmata intermedia, L. jundalini Rhyne, Calado \& dos Santos, 2012, L. moorei, L. napoleoni De Grave \& Anker, 2018, L. nilita, and L. seticaudata. The eastern-Pacific representatives of this group are L. argentopunctata, L. chica Wicksten, 2000, L. galapagensis, and L. holthuisi Anker, Baeza \& De Grave, 2009. However, only two species with long accessory ramus have been described from the Indo-West Pacific, L. ternatensis De Man, 1902, and L. trisetacea, in addition to L. zacae Armstrong, 1941 only being reported from the West Pacific.

Lysmata ternatensis shares with L. malagasy sp. nov. some traits like the rostral armament, i.e., 5-6 teeth on upper (including postrostral ones) and 2-3 on lower margins, the carapace with the pterygostomial tooth, the stylocerite not extending beyond midlength of the second antennular article, and the second pereiopod with the carpus composed of about 24 articles. Although no information about the carpal and meral spinulation of the three last pereiopods was provided by De Man (1902), it seems that these two species are similar in the latter character according to Xu \& Li (2015). Importantly, as discussed by De Grave \& Anker (2018), and according to personal observations by one of the authors (HA) on other congeners, i.e., L. vittata and L. kuekenthali, characters like the rostral armament, second pereiopod carpal segmentation, and carpal and meral spinulation on three last pereiopods, especially the third one, can be highly variable within a species and consequently untrustworthy for separating taxa. However, based on the original description (De Man 1902) and other published reports on L. ternatensis (e.g., Chace 1997; Xu \& Li 2015; Madhavan et al. 2019), the accessory ramus of the lateral antennular flagellum in L. ternatensis consists of 10 segments (10 to 15 segments were reported

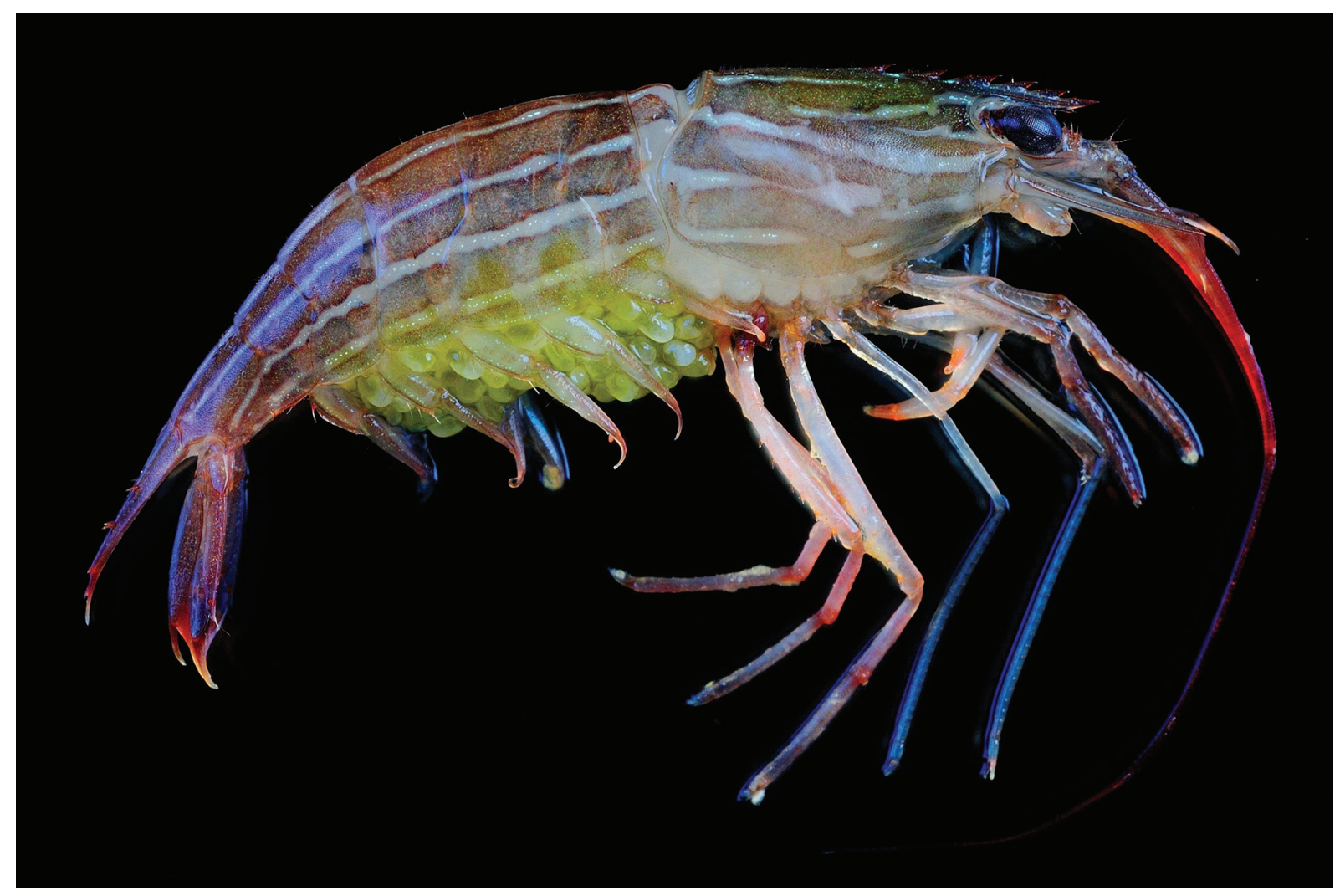

Fig. 7. Color pattern of the live holotype specimen of Lysmata malagasy sp. nov. (MNHN-IU-2010-4890). Photo by Tin-Yam Chan. Copyright MNHN. 
ASHRAFI H. et al., The caridean shrimps of the genus Lysmata Risso, 1816 from Madagascar

for material from the China Sea by Xu \& Li in 2015), thus their distinctly higher number clearly distinguishes $L$. ternatensis from L. malagasy sp. nov. In the latter, the accessory ramus consists of only four elongated articles. This can be the most reliable morphological character applicable to separate these two species. This difference can also be applied for distinguishing L. malagasy sp. nov. from the synonymized species under the name of L. ternatensis, Hippolysmata acicula Rathbun, 1906, Lysmata affinis Borradaile, 1915, and Palaemon dentatus De Haan, 1841. In the description of Hippolysmata acicula, Rathbun (1906) stated nothing about the state of the accessory ramus of the lateral antennular flagellum. However, the holotype material was re-examined by Chace (1997), who reported that the accessory ramus was comprised of 10 segments compared to four in the new species. In the description of Lysmata affinis, Borradaile (1915) only stated that $L$. affinis is related to L. seticaudata (Risso, 1816) and L. chiltoni Kemp, 1914; with no more information about the status of the antennular flagellum. However, Borradaile (1917) provided more information about L. affinis, and he described the accessory ramus of the antennular flagellum being as long as the fused part. This character can be used to distinguish between L. affinis and L. malagasy sp. nov. as in the latter one, the fused part of the antennular flagellum is much longer than the accessory ramus. Holthuis (1947) stated that in L. dentata (originally as Palaemon dentatus), the fused part and accessory ramus of the antennular flagellum are equal in size as in $L$. affinis. Thus, the same argument can be used to differentiate between $L$. dentata and L. malagasy sp. nov.

Two differences are notable between $L$. trisetacea and L. malagasy sp. nov: 1) the pterygostomial angle is without a tooth in the former species while the latter bears a small acute tooth there; and 2) the accessory ramus of the outer antennular flagellum of L. trisetacea consists of at least eight segments (Kemp 1914; Chace 1997) and is subequal in length to the fused portion of the flagellum (Heller 1862; Kemp 1914; Holthuis 1947) whereas in the new species, the accessory ramus includes four elongated segments and is noticeably shorter in length than the fused part. However, it is worth to notice that L. trisetacea Heller, 1861, and its synonyms L. pusilla Heller, 1862, and L. chiltoni Kemp, 1914, should be treated more carefully as there is a considerable difference between the proportion of the length of the free accessory ramus to that of the fused part of the outer flagellum. In the description of L. pusilla, Heller (1862) noted that the accessory ramus is about twice as long as the fused part while Kemp (1914) described $L$. chiltoni with the fused part and accessory ramus being equal in length.

Armstrong (1941), in the description of L. zacae, only mentioned that the lateral antennular flagellum is biramous. Okuno (1996) re-examined the type material of $L$. zacae, and yet did not describe the exact status of the lateral antennular flagellum. There are three characters which can be used to differentiate the new species from $L$. zacae as follows: first, the shape of the pterygostomial angle bearing a small tooth in L. malagasy sp. nov. vs rounded in L. zacae; second, the very short stylocerite in L. zacae reaching to the proximal third of the basal antennular segment compared to longer one in the new species overreaching the basal antennular segment; and third, the scaphocerite reaching to the end of the antennular peduncle in L. zacae while it distinctly surpassing the antennular peduncle in L. malagasy sp. nov.

Other members of the "long accessory ramous" clade of the genus Lysmata from other geographical regions can be more or less distinguishable from the new species by the number of segments of the fused part and of the accessory ramus of the lateral flagellum; L. intermedia with 17-18 and 3-4 articles (d'Udekem d'Acoz 2000), L. jundalini 18-24 and 3-4 (Rhyne et al. 2012), L. moorei 7-13 and 7-16 (Rathbun 1901; Pachelle et al. 2020), L. napoleoni 6-9 and 10-13 (De Grave \& Anker 2018), L. nilita 21-27 and 4-7 (Dohrn \& Holthuis 1950), L. seticaudata 20-38 and 8-15 (Dohrn \& Holthuis 1950), L. argentopunctata 13-15 and 13-17 (Wicksten 2000), L. chica 10-11 and 3-6 (Wicksten 2000), L. galapagensis 6-13 and 5-7 (Schmitt 1924), and L. holthuisi 17 and 6-7 articles (Anker et al. 2009), respectively. 
Lysmata kuekenthali (De Man, 1902)

Hippolyte kükenthali De Man, 1902: 850.

Hippolysmata kükenthali - Kemp 1914: 115, p. 6 fig. 2.

Hippolysmata (Hippolysmata) kükenthali - Holthuis 1947: 69.

\section{Diagnosis}

Carapace with rostrum reaching to between end of first antennular article to middle of third one, slightly up-turned distally, with four to seven teeth (mostly six) on dorsal margin including the Postrostral teeth, with greater gap between most posterior tooth and preceding one, bearing one to three teeth on ventral margin; antennal tooth strong, surpassing anterior margin of carapace, not fused with lower orbital angle; pterygostomial margin varying from rounded to bearing small tooth. Antennule with stylocerite subacute, falling short of end of first antennular segment; lateral flagellum with accessory free ramus composed of small one-segmented finger-liked projection. Antenna with inferior tooth of basicerite small, subacute; scaphocerite slightly overreaching antennular peduncle, disto-lateral tooth slightly surpassing blade, blade with anterior margin relatively straight, lateral margin slightly concave; carpocerite not reaching to end of second antennular segment.

First pereiopods small, robust; chela with very narrow gap between fingers at their proximal half when closed, fingers with small accessory tooth distally. Second pereiopods subequal, carpus with 17-22 segments. Third to fifth pereiopods generally similar, merus with two or three spinules on disto-lateral margin, dactylus biunguiculate, with two accessory spinules on flexor margin.

Pleon with three anterior pleura rounded antero- and postero-ventrally, fourth pleuron obtusely angulated postero-ventrally, fifth pleuron with small acute tooth postero-ventrally, six pleuron with triangular projection on postero-lateral angle flanking telson. Posterior margin of telson with subacute median projection and bearing two pairs of spines posteriorly, mesial spiniform setae longer than lateral ones.

\section{Material examined}

MADAGASCAR • 1 hermaphrodite; southern Madagascar; 254'23" S, 46 57'8" E; depth 14 -18 m; 8 May 2010; MNHN exped.; Atimo-Vatae; Stn. TB06; GenBank MW798242; MNHN-IU-2017-2377.

IRAN • 5 hermaphrodites; Ramin; Gulf of Oman; 2516'7.05" N, 6045'2.71" E; 5 Nov. 2008; A. Sari leg.; sandy/rocky with cobbles; GenBank MW798240; MNHN-IU-2014-1246 • 4 hermaphrodites; Ramin; Gulf of Oman; $25^{\circ} 16^{\prime} 7.05^{\prime \prime}$ N, 6045'2.71" E; 16 May 2018; H. Ashrafi leg.; sandy/rocky with cobbles; GenBank MW798241; MNHN-IU-2014-1247 • 13 hermaphrodites; same collection data as for preceding;

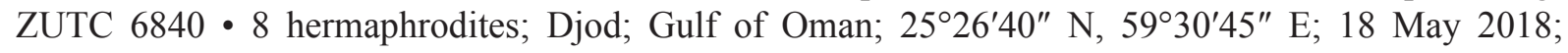
H. Ashrafi leg.; sandy/rocky with cobbles; ZUTC $6841 \cdot 8$ hermaphrodites; same collection data as for preceding; 7 Feb. 2009; H. Salehi leg.; sandy/rocky with cobbles; ZUTC 6842.

\section{Ecology}

No information about the ecology of the specimen collected in Madagascar is available. However, the specimens collected in the Gulf of Oman (by HA) were found at night in the lower intertidal zone in a deep tidal pool surrounded by large rocks, together with Palaemon pacificus (Stimpson, 1860). More than 100 individuals of L. kuekenthali, and around 30 of P. pacificus, were in the same tidal pool. 


\section{Distribution}

Although this species has been recorded from many localities in the Indo-West Pacific (see Kemp 1914; Holthuis 1947; Chace 1997; Anker \& De Grave 2016; Ashrafi et al. 2020), this is the first record of this species from Madagascar.

\section{Lysmata lipkei Okuno \& Fiedler, 2010}

Fig. 8

Lysmata lipkei Okuno \& Fiedler 2010: 599, figs 1-4.

\section{Diagnosis}

Carapace with rostrum reaching to about middle of second antennular article, armed with 4-5 teeth on dorsal margin (including two postorbital ones) and 2-4 on ventral margin; antennal tooth welldeveloped; pterygostomial angle with small acute tooth. Antennule with stylocerite subacute, falling short of reaching to end of first antennular segment; lateral flagellum with accessory ramus consisting of short one-segmented finger-shaped article. Antenna with inferior tooth of basicerite strong; scaphocerite distinctly surpassing antennular peduncle, lateral margin slightly concave, distolateral tooth slightly overreaching blade; carpocerite small, not reaching to end of first antennular article.

First pereiopod robust, chela with fingers bearing a narrow gap when closed, especially on proximal half. Second pereiopods unequal in size, longer one with 27-32 and shorter one with 23-27 carpal segments. Third pereiopod with merus armed with spinules on distal 0.6 of segment length; carpus unarmed; dactylus biunguiculate, ventral margin with two or three accessory spines, decreasing in size toward

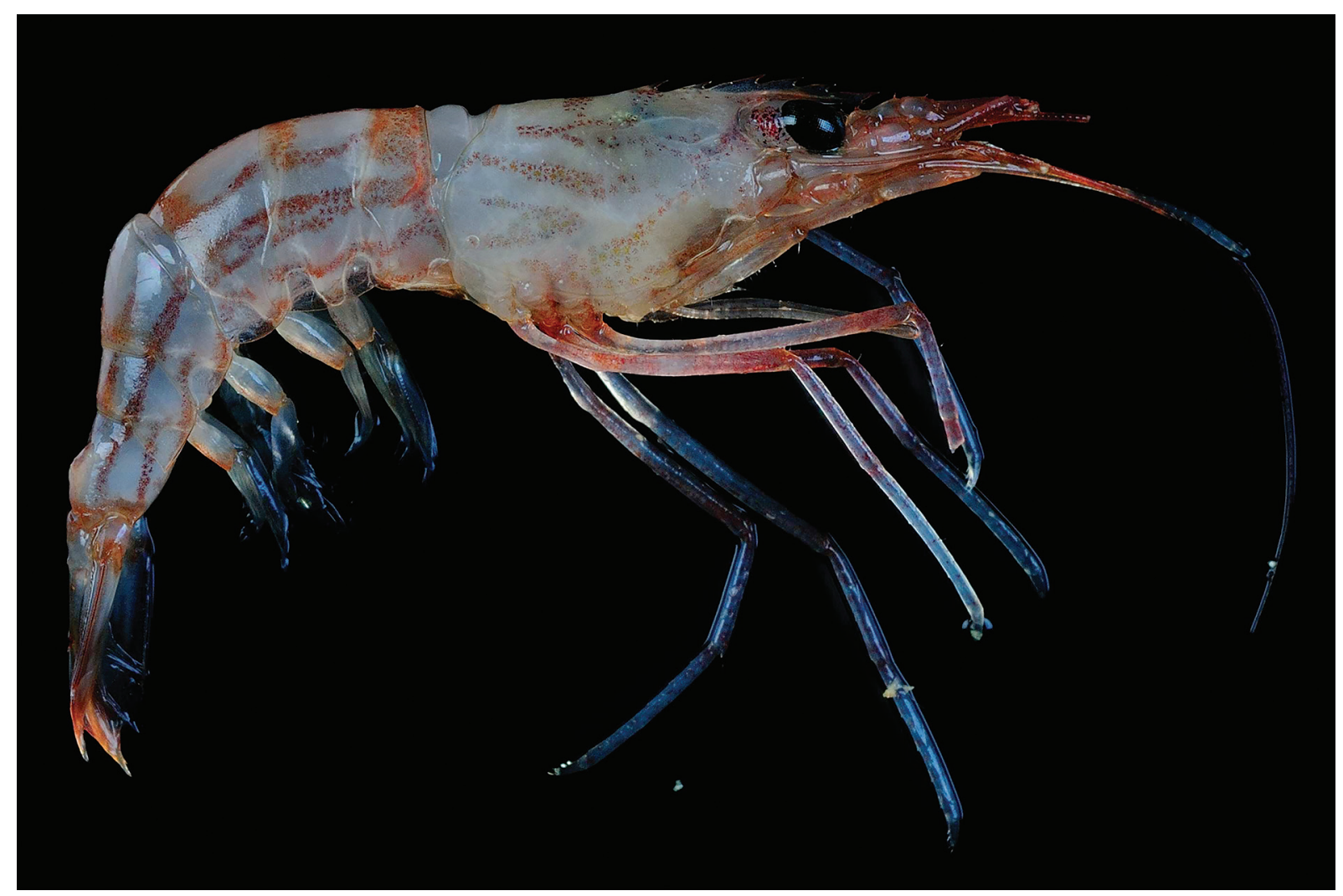

Fig. 8. Color pattern of the live ovigerous hermaphrodite, Lysmata lipkei Okuno \& Fiedler, 2010. Photo by Tin-Yam Chan \& Chia-Wei Lin. Copyright MNHN. 
proximal margin (in case of having three accessory teeth, proximal one very small). Fifth pereiopod with merus armed with 1-3 spinules disto-ventrally.

Pleon with three anterior pleura rounded antero- and postero-ventrally, fourth pleuron angled posteroventrally, fifth pleuron with small acute tooth postero-ventrally. Posterior margin of telson with small acute median projection and two pairs of spines, with mesial pair stronger and longer than lateral pair.

\section{Material examined}

MADAGASCAR - 1 hermaphrodite; southern Madagascar; 25⒉ $26.4^{\prime} \mathrm{S}, 4^{\circ} 56.1^{\prime} \mathrm{E}$; depth 14-18 m; 29 May 2010; MNHN exped.; Atimo-Vatae; Stn. BS03; GenBank MW798243; MNHN-IU-2010-4898.

\section{Remarks}

Although the lateral flagella of the two antennules in the single studied specimen of L. lipkei from Madagascar are broken, all other morphological characters, as well as molecular data, are consistent with the description and variability provided by Okuno \& Fiedler (2010), except for one character - the number of accessory spinules on the flexor margin of the biunguiculate dactyli of the last three pereiopods. In the original description, there are three accessory spinules decreasing in size proximally, while only two accessory spinules are seen in the material of the present study. This single difference can be interpreted as inter-population variation, as specimens of Japan and Madagascar are very close genetically.

\section{Distribution}

This is the seventh record of L. lipkei. After being originally described from Japan by Okuno \& Fiedler (2010), reported again from Japan by De Grave et al. (2012), and subsequently reported from Singapore by Anker \& De Grave (2016); this species, based on morphological and genetic data, was recorded from the south-western Atlantic Ocean, Brazil, and classified as alien there by Alves et al. (2018) as well two other records from Brazil (Pachelle et al. 2016, 2020). The present report on L. lipkei from Madagascar significantly extends its known Indo-West Pacific range to the south-west Indian Ocean.

\section{Discussion}

Although the western Atlantic $L$. hochi has recently been reported from India as a non-indigenous species (Jose et al. 2020), the present results of the phylogenetic reconstruction allow to suggest contrarily that $L$. hochi is in fact the IWP species $L$. kuekenthali introduced to the Caribbean Sea. The only morphological difference between L. hochi and L. kuekenthali stated by Jose et al. (2020) is the bifid stylocerite of the former species. However, in the original description of $L$. hochi, Baeza \& Anker (2008: 149) reported on the stylocerite as being "usually bifid". It is thus evident that this character varies in the latter species.

The present material of $L$. kuekenthali from the Gulf of Oman shows variability in the pterygostomial angle which is rounded in larger specimens (see also remarks for L. kuekenthali by Kemp in 1914-and Chace in 1997) but with a small tooth in smaller specimens. All other characters are completely consistent between L. hochi and L. kuekenthali. Additionally, the color pattern shown for L. hochi by Baeza \& Anker (2008: fig. 2) and Jose et al. (2020: fig. 2) is very similar to that of L. kuekenthali (Ashrafi et al. 2020: fig. 1d).

The western Atlantic L. hochi might be conspecific with the IWP L. kuekenthali. However, additional studies focusing on both color pattern as well as morphological and genetic characters from specimens collected from more localities are needed to support this last claim, considering that L. kuekenthali was suggested to represent a species complex by Anker \& De Grave (2016).

In the past decade, four species of Lysmata have been reported as alien and/or invasive (Soledade et al. 2013; Froglia \& Deval 2014; Alves et al. 2018; Jose et al. 2020). Among all the possible mechanisms 
ASHRAFI H. et al., The caridean shrimps of the genus Lysmata Risso, 1816 from Madagascar

involved in the introduction of invertebrates, including crustaceans (e.g., ship transport and intentional introductions - Rodríguez \& Suárez 2001; Hänfling et al. 2011), the aquarium trade seems to play an important role in shrimps (Rhyne et al. 2009; Baeza \& Behringer 2017). Peppermint shrimps are highly popular in the aquarium trade given their striking coloration, the ability for controlling pests, and for cleaning fish from parasites (Bauer 2000; Rhyne et al. 2004; Calado 2008; Rhyne et al. 2009).

\section{Acknowledgments}

The Atimo Vatae expedition, with the aim of exploring coastal marine fauna and flora, was conducted under the umbrella of the "Our Planet Reviewed" programme by Museum national d'histoire naturelle (MNHN) in 2010 and Pro Natura International (PNI) in partnership with Institut d'Halieutique et des Sciences Marines, University of Toliara (IH.SM) and the Madagascar bureau of Wildlife Conservation Society (WCS). The Atimo Vatae expedition was financially supported also by Prince Albert II and Niarchos Foundations. This study was financed from the Student grant project SGS03/PřF/2021 of University of Ostrava (HA). The first and the senior authors greatly appreciate the generous help of Dr Laure Corbari (MNHN) during their research visiting MNHN, and for loaning examined specimens. We also deeply appreciate the valuable comments of two anonymous referees who truly helped us to improve this work.

\section{References}

Alves D.F.R., Lima D.J.M., Hirose G.L., Martinez P.A., Dolabella S.S. \& Barros-Alves S. 2018. Morphological and molecular analyses confirm the occurrence of two sympatric Lysmata shrimp (Crustacea, Decapoda) in the southwestern Atlantic. Zootaxa 4526: 41-55.

https://doi.org/10.11646/zootaxa.4526.1.3

Anker A., Baeza J.A. \& De Grave S. 2009. Anew species of Lysmata (Crustacea, Decapoda, Hippolytidae) from the Pacific coast of Panama, with observations of its reproductive biology. Zoological Studies 48: 682-692.

Anker A. \& Cox D. 2011. A new species of the shrimp genus Lysmata Risso, 1816 (Crustacea, Decapoda) from Guam. Micronesica 41: 197-214.

Anker A. \& De Grave S. 2016. An updated and annotated checklist of marine and brackish caridean shrimps of Singapore (Crustacea, Decapoda). Raffles Bulletin of Zoology 34: 343-454.

Armstrong J.C. 1941. The Caridea and Stomatopoda of the second Templeton Crocker-American Museum Expedition to the Pacific Ocean. American Museum Novitates 1137: 1-14.

Ashrafi H., Dehghani A., Sari A. \& Naderloo R. 2020. An updated checklist of caridean shrimps of the Persian Gulf and Gulf of Oman. Zootaxa 4747: 521-534. https://doi.org/10.11646/zootaxa.4747.3.6

Aznar-Cormano L., Brisset J., Chan T.-Y., Corbari L., Puillandre N., Utge J., Zbinden M., Zuccon D. \& Samadi S. 2015. An improved taxonomic sampling is a necessary but not sufficient condition for resolving inter-families relationships in Caridean decapods. Genetica 143: 195-205. https://doi.org/10.1007/s10709-014-9807-0

Baeza J.A. 2010. Molecular systematics of peppermint and cleaner shrimps: phylogeny and taxonomy of the genera Lysmata and Exhippolysmata (Crustacea: Caridea: Hippolytidae). Zoological Journal of the Linnean Society 160: 254-265. https://doi.org/10.1111/j.1096-3642.2009.00605.x

Baeza J.A. \& Anker A. 2008. Lysmata hochi n. sp., a new hermaphroditic shrimp from the southwestern Caribbean sea (Caridea: Hippolytidae). Journal of Crustacean Biology 28: 148-155. https://doi.org/10.1651/07-2839R.1 
Baeza J.A. \& Behringer D.C. 2017. Integrative taxonomy of the ornamental "peppermint" shrimp public market and population genetics of Lysmata boggessi, the most heavily traded species worldwide. PeerJ 5: e3786. https://doi.org/10.7717/peerj.3786

Baeza J.A. \& Fuentes M.S. 2013. Exploring phylogenetic informativeness and nuclear copies of mitochondrial DNA (numts) in three commonly used mitochondrial genes: mitochondrial phylogeny of peppermint, cleaner, and semi-terrestrial shrimps (Caridea: Lysmata, Exhippolysmata, and Merguia). Zoological Journal of the Linnean Society 168: 699-722. https://doi.org/10.1111/zoj.12044

Baeza J.A. \& Prakash S. 2019. An integrative taxonomic and phylogenetic approach reveals a complex of cryptic species in the "peppermint" shrimp Lysmata wurdemanni sensu stricto. Zoological Journal of the Linnean Society 185: 1018-1038. https://doi.org/10.1093/zoolinnean/zly084

Baeza J.A., Schubart C.D., Zillner P., Fuentes S. \& Bauer R.T. 2009. Molecular phylogeny of shrimps from the genus Lysmata (Caridea: Hippolytidae): the evolutionary origins of protandric simultaneous hermaphroditism and social monogamy. Biological Journal of the Linnean Society 96: 415-424. https://doi.org/10.1111/j.1095-8312.2008.01133.x

Bauer R.T. 2000. Simultaneous hermaphroditism in caridean shrimps: a unique and puzzling sexual system in the Decapoda. Journal of Crustacean Biology 20: 116-128.

https://doi.org/10.1163/1937240X-90000014

Borradaile L.A. 1915. Notes on Carides. The Annals and Magazine of Natural History 15: 205-213. https://doi.org/10.1080/00222931508693629

Borradaile L.A. 1917. The Percy Sladen Trust Expedition to the Indian Ocean in 1905, under the leadership of Mr. J. Stanley Gardiner, M.A. No. IX. - On Carides from the Western Indian Ocean. Transactions of the Linnean Society of London (2) Zoology 17: 397-412.

https://doi.org/10.1111/j.1096-3642.1917.tb00471.x

Calado R. 2008. Marine Ornamental Shrimp: Biology, Aquaculture and Conservation. Wiley and Blackwell.

Castresana J. 2000. Selection of conserved blocks from multiple alignments for their use in phylogenetic analysis. Molecular Biology and Evolution 17: 540-552.

https://doi.org/10.1093/oxfordjournals.molbev.a026334

Chace F.A.J. 1997. The caridean shrimps (Crustacea: Decapoda) of the Albatross Philippine Expedition, 1907-1910, Part 7: Families Atyidae, Eugonatonotidae, Rhynchocinetidae, Bathypalaemonellidae, Processidae, and Hippolytidae. Smithsonian Contributions to Zoology 587: 1-106. https://doi.org/10.5479/si.19436696.391.1

Crandall K.A. \& Fitzpatrick Jr J. 1996. Crayfish molecular systematics: using a combination of procedures to estimate phylogeny. Systematic Biology 45: 1-26. https://doi.org/10.1093/sysbio/45.1.1

Crosnier A. \& Forest J. 1973. Les crevettes profondes de 1'Atlantique oriental tropical. Faune tropicale 19: $1-409$.

De Grave S. \& Anker A. 2018. A new, distinctly coloured species of Lysmata Risso, 1816 (Malacostraca: Decapoda: Lysmatidae) from the south-central Atlantic. Zootaxa 4429: 390-400. https://doi.org/10.11646/zootaxa.4429.2.13

De Grave S. \& Fransen C.H.J.M. 2011. Carideorum catalogus: the recent species of the dendrobranchiate, stenopodidean, procarididean and caridean shrimps (Crustacea: Decapoda). Zoologische Mededelingen (Leiden) 85: 195-588.

De Grave S., Chan T.-Y., Fujita Y. \& Okuno J. 2012. Hippolytidae and Barbouriidae (Decapoda: Caridea) collected during the Ryukyu "KUMEJIMA 2009" expedition. In: Naruse T., Chan T.-Y., 
ASHRAFI H. et al., The caridean shrimps of the genus Lysmata Risso, 1816 from Madagascar

Tan H.H., Ahyong S.T. \& Reimer J.D. (eds) Scientific Results of the Marine Biodiversity Expedition KUMEJIMA 2009. Zootaxa 3367: 95-102. https://doi.org/10.11646/zootaxa.3367.1.9

De Grave S., Li C.P., Tsang L.M., Chu K.H. \& Chan T.-Y. 2014. Unweaving hippolytoid systematics (Crustacea, Decapoda, Hippolytidae): resurrection of several families. Zoologica Scripta 43: 496-507. https://doi.org/10.1111/zsc.12067

De Man J.G. 1902. Die von Herrn Professor Kükenthal im Indischen Archipel gesammelten: Dekapoden und Stomatopoden. Abhandlungen der Senckenbergischen Naturforschenden Gesellschaft 25: 466-929. https://doi.org/10.5962/bhl.title.10409

Dohrn P. \& Holthuis L.B. 1950. Lysmata nilita, a new species of prawn (Crustacea Decapoda) from the western Mediterranean. Pubblicazioni della Stazione Zoologica di Napoli 22: 339-347.

d'Udekem d'Acoz C. 2000. Redescription of Lysmata intermedia (Kingsley, 1879) based on topotypical specimens, with remarks on Lysmata seticaudata (Risso, 1816) (Decapoda, Caridea, Hippolytidae). Crustaceana 73: 719-735. https://doi.org/10.1163/156854000504750

Edgar R.C. 2004. MUSCLE: multiple sequence alignment with high accuracy and high throughput. Nucleic Acids Reearch 32: 1792-1797. https://doi.org/10.1093/nar/gkh340

Fiedler G.C., Rhyne A.L., Segawa R., Aotsuka T. \& Schizas N.V. 2010. The evolution of euhermaphroditism in caridean shrimps: a molecular perspective of sexual systems and systematics. BMC Evolutionary Biology 10: 297. https://doi.org/10.1186/1471-2148-10-297

Fransen C.H.J.M. 1991. Lysmata olavoi, a new shrimp of the family Hippolytidae (Decapoda, Caridea) from the eastern Atlantic Ocean. Arquipélago-Life and Earth Sciences 9: 63-73.

Froglia C. \& Deval M. 2014. First record of an exotic hippolytid shrimp in the eastern Mediterranean Sea. Mediterranean Marine Science 15: 168-171. https://doi.org/10.12681/mms.651

Hänfling B., Edwards F. \& Gherardi F. 2011. Invasive alien Crustacea: dispersal, establishment, impact and control. BioControl 56: 573-595. https://doi.org/10.1007/s10526-011-9380-8

Holthuis L.B. 1947. The Decapoda of the Siboga Expedition. Part IX. The Hippolytidae and Rhynchocinetidae collected by the Siboga and Snellius expeditions with remarks on other species. Siboga Expéditie 39a8: 1-100.

Heller C. 1861. Synopsis der im rothen Meere vorkommenden Crustaceen. Verhandlungen der Zoologisch-Botanischen Gesellschaft in Wien 11: 3-32.

Heller C. 1862. Beiträge zur Crustaceen-Fauna des Rothen Meeres. II. Sitzungsberichte der Akademie der Wissenschaften in Wien 44: 241-295. https://doi.org/10.5962/bhl.title.120013

Horká I., De Grave S., Fransen C.H.J.M., Petrusek A. \& Duriš Z. 2016. Multiple host switching events shape the evolution of symbiotic palaemonid shrimps (Crustacea: Decapoda). Scientific Reports 6: 26486. https://doi.org/10.1038/srep26486

Jose S., Purushothaman P., Madhavan M., Akash S., Bharathi S., Dhinakaran A., Kumar T.A. \& Lal K. 2020. Two new records of hippolytoid shrimps, Lysmata hochi Baeza \& Anker, 2008 (Decapoda: Lysmatidae) and Lysmata amboinensis (de Man, 1888) from Lakshadweep Islands, India with taxonomic notes. Zootaxa 4755: 353-364. https://doi.org/10.11646/zootaxa.4755.2.9

Kalyaanamoorthy S., Minh B.Q., Wong T.K.F., Haeseler A. von \& Jermiin L.S. 2017. ModelFinder: Fast model selection for accurate phylogenetic estimates. Nature Methods 14: 587-589. https://doi.org/10.1038/nmeth.4285

Kemp S. 1914. Notes on Crustacea Decapoda in the Indian Museum. V. Hippolytidae. Records of the Indian Museum 10: 81-129. https://doi.org/10.5962/bhl.part.5624 
Kingsley J.S. 1878. Notes on the North American Caridea in the Museum of the Peabody Academy of Science at Salem, Mass. Proceedings of the Academy of Natural Sciences of Philadelphia 30: 89-98.

Kumar S., Stecher G., Li M., Knyaz C. \& Tamura K. 2018. MEGA X: Molecular Evolutionary Genetics Analysis across computing platforms. Molecular Biology and Evolution 35: 1547-1549. https://doi.org/10.1093/molbev/msy096

Letunic I. \& Bork P. 2011. Interactive Tree Of Life v2: online annotation and display of phylogenetic trees made easy. Nucleic Acids Research 39: 1-4. https://doi.org/10.1093/nar/gkr201

Madhavan M., Purushothaman P., Akash S., Bharathi S., Jose S., Dhinakaran A., Ravi C., Kumar T.A. \& Lal K. 2019. New record of Thor hainanensis Xu \& Li, 2014 and taxonomical remarks on Lysmata ternatensis de Man, 1902 (Decapoda: Thoridae \& Lysmatidae) from the Lakshadweep Islands, India. Zootaxa 4624: 351-364. https://doi.org/10.11646/zootaxa.4624.3.4

Okuno J. 1996. Lysmata zacae Armstrong, 1941, rediscovery from Southern Japan and New Caledonia (Crustacea, Decapoda, Hippolytidae). Species Diversity 1: 49-54. https://doi.org/10.12782/specdiv.1.49

Okuno J. \& Fiedler G.C. 2010. Lysmata lipkei, a new species of peppermint shrimp (Decapoda, Hippolytidae) from warm temperate and subtropical waters of Japan. Crustaceana Monograph, 2010: 597-610. https://doi.org/10.1163/9789047427759_042

Pachelle P.P., Anker A., Mendes C.B. \& Bezerra L.E. 2016. Decapod crustaceans from the state of Ceará, northeastern Brazil: an updated checklist of marine and estuarine species, with 23 new records. Zootaxa 4131: 1-63. https://doi.org/10.11646/zootaxa.4131.1.1

Pachelle P.P., Carvalho L., Alves D.F. \& Anker A. 2020. A revision of the Brazilian species of Lysmata Risso, 1816 (Decapoda: Caridea: Lysmatidae), with discussion of the morphological characters used in their identification. Zootaxa 4789: 55-90. https://doi.org/10.11646/zootaxa.4789.1.2

Palumbi S.R. \& Benzie J. 1991. Large mitochondrial DNA differences between morphologically similar penaeid shrimp. Molecular Marine Biology and Biotechnology 1: 27-34.

Rathbun M.J. 1901. The Brachyura and Macrura of Porto Rico. Bulletin of the United States Fish Commission 20: 1-127.

Rathbun M.J. 1906. The Brachyura and Macrura of the Hawaiian islands. Bulletin of the Bureau of Fisheries 23: 827-930.

Rhyne A.L. \& Lin J. 2006. A western Atlantic peppermint shrimp complex: redescription of Lysmata wurdemanni, description of four new species, and remarks on Lysmata rathbunae (Crustacea: Decapoda: Hippolytidae). Bulletin of Marine Science 79: 165-204.

Rhyne A.L., Lin J. \& Deal K.J. 2004. Biological control of aquarium pest anemone Aiptasia pallida Verrill by peppermint shrimp Lysmata Risso. Journal of Shellfish Research 23: 227-230.

Rhyne A.L., Rotjan R., Bruckner A. \& Tlusty M. 2009. Crawling to collapse: ecologically unsound ornamental invertebrate fisheries. PLoS ONE 4: e8413. https://doi.org/10.1371/journal.pone.0008413

Rhyne A.L., Calado R. \& Dos Santos A. 2012. Lysmata jundalini, a new peppermint shrimp (Decapoda, Caridea, Hippolytidae) from the Western Atlantic. Zootaxa 3579: 71-79.

https://doi.org/10.11646/zootaxa.3579.1.4

Rodríguez G. \& Suárez H. 2001. Anthropogenic dispersal of decapod crustaceans in aquatic environments. Interciencia 26: 282-288.

Ronquist F. \& Huelsenbeck J.P. 2003. MrBAYES 3: Bayesian phylogenetic inference under mixed models. Bioinformatics 19: 1572-1574. https://doi.org/10.1093/bioinformatics/btg180 
Schmitt W.L. 1924. Bijdragen tot the de kennis der fauna van Curaçao. Resultaten eener reis van Dr. C.J. van der Horst in 1920. The macruran, anomuran and stomatopod Crustacea. Bijdragen tot de Dierkunde 23: 61-82. https://doi.org/10.1163/26660644-02301005

Soledade G.O., Baeza J.A., Boehs G., Simões S.M., Souza Santos P., Caetano da Costa R. \& Almeida A.O. 2013. A precautionary tale when describing species in a world of invaders: morphology, coloration and genetics demonstrate that Lysmata rauli is not a new species endemic to Brazil but a junior synonym of the Indo-Pacific L. vittata. Journal of Crustacean Biology 33: 66-77. https://doi.org/10.1163/1937240X-00002122

Wang Y.-R. \& Sha Z.-L. 2018. Description of two new species of Lysmata Risso, 1816 (Decapoda, Lysmatidae) from the China seas, with remarks on Lysmata vittata (Stimpson 1860). Zootaxa 4392: 28-40. https://doi.org/10.11646/zootaxa.4392.1.2

Wicksten M.K. 2000. The species of Lysmata (Caridea: Hippolytidae) from the Eastern Pacific Ocean. Amphipacifica 2: 3-22. https://doi.org/10.1163/156854000504273

Xu P. \& Li X. 2015. Report on the Hippolytidae Bate (sensu lato) from China seas. Zoological Systematics 40: $107-165$.

Manuscript received: 3 May 2021

Manuscript accepted: 24 June 2021

Published on: 12 October 2021

Section editor: Rudy Jocqué

Desk editor: Fariza Sissi

Printed versions of all papers are also deposited in the libraries of the institutes that are members of the EJT consortium: Muséum national d'histoire naturelle, Paris, France; Meise Botanic Garden, Belgium; Royal Museum for Central Africa, Tervuren, Belgium; Royal Belgian Institute of Natural Sciences, Brussels, Belgium; Natural History Museum of Denmark, Copenhagen, Denmark; Naturalis Biodiversity Center, Leiden, the Netherlands; Museo Nacional de Ciencias Naturales-CSIC, Madrid, Spain; Real Jardín Botánico de Madrid CSIC, Spain; Zoological Research Museum Alexander Koenig, Bonn, Germany; National Museum, Prague, Czech Republic. 